\title{
ATTITUDES TOWARD BIRTH CONTROL IN BANDUNG, INDONESIA
}

\author{
R. Murray Thomas
}

One of the less publicized but perhaps most significant policy changes of the Indonesian government since 1965 has been its apparent tendency to shift its stand on the question of birth control. In the years prior to the unsuccessful coup of October 1965, the government officially maintained an anti-birth control position, as was clearly shown in press releases from government spokesmen. ${ }^{1}$ But in 1966, and more prominently in 1967, family planning appeared to be looked upon with increasing official favor. A nationally publicized symposium on contraception was conducted in Bandung, West Java, at the end of January 1967 sponsored by the medical faculty of Padjadjaran University, a prominent state institution. ${ }^{2}$ Although public health officials at this time said family planning was "not yet" the government's official policy, they openly supported birth control measures aimed at protecting the health of mothers and children. ${ }^{3}$ Newspaper articles authored by scientists, physicians, and representatives of Islamic and Christian groups expressed favorable views of birth control. ${ }^{4}$ This new public atmosphere suggested that the political leadership, or at least an influential segment of it, might hope to institute birth control measures.

1. Atang-R, "Membatasi Kelahiran," Pikiran Rakjat, February 26 , $1965, \mathrm{pp}$. 1,3 .

2. "Bandung Symposium on Contraception," Djakarta Times, January 31 , 1967, p. 2; A. Pamusureng, "Sekilas Tjoretan dari Simposium Kontrasepsi (2)," Harapan Rakjat, January 28,1967, p. 2; "4 Tjara Untuk Batasi Hamil," Pikiran Rakjat, Angkatan Bersendjata, February 2, $1967, \mathrm{p} .3$; and "Kontrasepsi dari Segi Agama Islam," Surabaja Post, February I, 1967, p. 1 .

3. "'Keluarga Berentjana' Belum Merupakan Policy Resmi Pemerintah," Sinar Harapan, February 2, 1967, p. 1.

4. See, for example, "Metode 'Loop, " Pikiran Rakjat, Angkatan Bersendjata, July 15, 1966, P. I; "Menurut Islam Tak Terlarang," Pikiran Rakjat, Angkatan Bersendjata, February 8, 1967, P. 3; and Sarwono Prawirohardjo, "Family Planning," Harian Operasi, March 8, 1967, p. 2 . 
As government officials and outside observers in 1966-67 have tried to estimate the likelihood that a birth control campaign would succeed in Indonesia, they have found themselves without clear evidence about a crucial question: What are the attitudes of the Indonesian populace toward birth control? In other words, a government birth control plan obviously would not reduce population growth unless the plan enjoyed widespread, sincere endorsement; so officials might find it helpful in estimating the job ahead of them if they knew at the outset the attitudes of different segments of society toward birth control issues.

Since there seem to be little or no available data about Indonesians' views on family planning matters, it would seem any survey information, however modest, that might be contributed about attitudes toward birth control would be welcome. The present article is offered as such a modest contribution. The article consists of: (1) a brief summary of the problem of overpopulation in Indonesia and of the principal techniques adopted for dealing with the problem prior to 1967, and (2) a report of the results of a small study of attitudes toward birth control which the writer and a team of graduate students conducted early in 1965 in the city of Bandung.

\section{The Population Probram}

Indonesia, with more than 109 million people by the end of 1966, was the world's fifth most populous country. 5 At an annual growth rate of approximately 3.0 percent, the number of Indonesians should double by $1989 .^{6}$

The distribution of people throughout the archipelago is very uneven. Java and its small companion island of Madura represent less than 7 percent of the nation's land area but contain 62 percent of the population. Kalimantan (Indonesian Borneo) represents 28 percent of the land area but only 4 percent

5. This estimate is derived from computing a conservative 2.5 percent growth on the 97 million established in the census of 1961. Sensus Penduduk 1961, Republik Indonesia (Djakarta: Biro Pusat Statistik, 1963), p. I.

6. Although Indonesian statisticians have used a growth-rate estimate of 2.3 for the latter years of the $1950^{\prime} \mathrm{s}$ and the early $1960^{\prime} \mathrm{s}$, Keyfitz determined that the rate was at least 2.5 and perhaps had already reached 3 percent by the mid$1960^{\prime} \mathrm{s}$. See Nathan Keyfitz, "Population in Indonesia--The Short and Long Run," Workshop Masalah Penduduk (Djakarta: Lembaga Penjelidikan Ekonomi dan Masjarakat, Fakultas Ekonomi, Universitas Indonesia, 1964). 
of the population. West Irian (Western New Guinea) has 22 percent of the land but less than one percent of the people. This makes Java, with about 480 people per square kilometer, one of the most crowded areas of the earth; while Kalimantan with eight people per square kilometer and West Irian with less than two are among the sparsest. ${ }^{7}$

Since 1900 the problem of overcrowding on Java has been a matter of concern for policy-makers, a solution being sought in colonial times largely via the transmigration of Javanese to other islands. It was only on the eve of World War II that a significant effort was made, however: the number who migrated with government aid in 1933 was 751 , in 1935 about 15,000 , in 1940 nearly 53,000, and in 1941 approximately 60,000.8 The accelerated population growth of the 1950's and early 1960's greatly exacerbated the situation, and by mid-1960 both Indonesians and foreign observers agreed that unless strong measures were applied right away to relieve the rapid impacting of Java, social disorder would ensue as the result of the development of an unbearable population density within an unstable political order and a deteriorating economy. 9

The three most apparent possibilities for solving the overcrowding were to increase transmigration, to initiate a birth control program, and/or to improve the economy enough to sustain an expanding population. Of these possibilities, the third was the least tenable as a short-run solution. In the 1960's the economy was not sufficiently viable to support a stable Java population of 65 million properly, much less care for a growth of one or two million people a year. And in the long run, even the healthiest of economies would not alone suffice as a solution to the problems of overpopulation, as Java is approaching the point where density is too great for the wellbeing of even an industrialized society. Indeed, at a conservative growth rate of only 2.5 percent, the population of Java in 150 years would be more than the whole world's

7. For a discussion of population distribution and density, see Karl J. Pelzer, "Physical and Human Resource Patterns," in Ruth MoVey (ed.), Indonesia (New Haven, Conn.: HRAF Press, 1963), pp. 14-15. For an analysis of the origin and response to the population problem, see Nathan Keyfitz, "Indonesian Population and the European Industrial Revolution," Asian Survey (V, 10), October 1965.

8. Karl J. Pelzer, Pioneer Settlement in the Asiatic Tropics (New York: Institute of Pacific Relations, 1945), p. 211.

9. See Nathan Keyfitz, "Population in Indonesia--The Short and Long Run"; Nathan Keyfitz and Widjojo Nitisastro, Soal Penduduk dan Pembangunan Indonesia (Djakarta: Pembangunan, 1964). 
population is today. People would literally be standing elbow to elbow. 10

Of the two remaining solutions, transmigration alone was accepted by the Indonesian government. President Sukarno consistently and forcefully rejected the idea of birth control, and his word became government policy. He was quoted in the late 1950's as saying, "Our people are unspoiled and we don't want them spoiled. Binth control in the West has conduced to loose morals."Il And in 1964, "I still believe we ought not to have birth control here. My solution is exploit more land-because if we exploit all the land in Indonesia you can feed 250 million people." 12

The anti-birth control policy of the government was not enforced in any strict sense. Hospitals were allowed to furnish birth control information and contraceptive devices to whoever sought them.13 Occasionally during 1960-1964 Mrs. Subandrio, wife of the first deputy prime minister, was quoted in the press as advocating birth control when speaking before women's groups. However, most references to population control in the press and over the radio stressed transmigration as the road to salvation and declared that birth control measures were unnecessary.

Any objective analysis of the population situation during these years showed that transmigration could not be considered seriously as a solution to the problem. Most Javanese did not want to leave their own villages to try taming jungle lands for agricultural purposes among unfriendly peoples in sumatra and Kalimantan. And of those who did transmigrate, some always

10. Nathan Keyfitz, "Population in Indonesia--The Short and Long Run," p. 2 .

11. Louis Fischer, The Story of Indonesia (New York: Harper, 1959), P. 165 .

12. "A Talk with Sukarno," Newsweek, October 5, 1964, p. 56.

13. A. Pamusureng, "Sekilas Tjoretan dari Simposium Kontrasepsi (5)," Harapan Rakjat, February 1, 1967, p. 2. This newspaper article indicates that the medical faculty at Padjadjaran University had been quietly offering interuterine devices to women since 1963. Dr. Niel Thrasher, the American director of the Seventh Day Adventist Hospital in Bandung, reported in an interview with the writer in July 1966, that the hospital had for some months been supplying free interuterine devices to women, with the quiet approval of the West Java govennor's office, the military commander, and the Islamic leaders of the area. 
returned to Java. ${ }^{14}$ However, even if large numbers of peasants had wanted to move, they were generally unable to finance the voyage themselves or to sustain life in the new environment for the year or more they would need to become self-supporting. It is true that the government could and did provide some financial aid to a limited number of transmigrants, but in comparison to the job to be done, the department in charge of transmigration had a mere pittance available for its work. The number of transmigrants from Java in the $1960^{\circ} \mathrm{s}$ apparently averaged around 20,000 or so a year, while the population of the island was growing by more than $1,500,000$ annually. 15

During the spring of 1965 the writer and a team of Indonesian graduate students in social psychology sought to learn something of the attitudes toward birth control of different segments of the population, at a time when the government, under sukarno, persisted in rejecting it.

More specifically, the team set out first to learn whether: (1) the people interviewed in Bandung agreed with the President that birth control measures were not needed to relieve overcrowding, (2) men agreed with women on this matter, (3) young people agreed with older ones, (4) people on three socioeconomic strata agreed with each other, and (5) students preparing for careers in social work held opinions representative of the general population.

In addition to investigating the foregoing questions, the team wished to discover what opinions the Bandung populace held on the other aspects of the birth control issue treated in the questionnaire items. This paper reports the team's findings and suggests several implications that the results may hold.

\section{Research Procedure}

The reader should recognize at the outset the conditions under which the study reported here was conducted, for these conditions explain why the sampling was so limited and why the questions posed for respondents were in some instances not so well cast as they might have been.

During the 1964-65 academic year the writer taught social psychology to master's degree candidates in the state college of education in Bandung. As an exercise in attitude measurement,

14. See, for example, "Transmigran Jang Pulang Kekampung Asal," Surabaja Post, February 3, 1967, p. 2.

15. Statistical Pocketbook of Indonesia 1963 (Djakarta: Biro Pusat Statistik, 1963), Pp. 11, 24. 
students were asked to propose social attitude issues that were both important to Indonesia's social development and feasible to measure. One of these issues was to become the basis for an instrument the class would construct and administer to a sample of respondents in Bandung. The class selected birth control as the topic, and students composed items for a birth control attitudes scale. From a list of more than 200 items, a student committee along with the instructor selected twenty-four which they believed would represent steps on a scale from very pro- to very anti-birth control attitudes.

In determining the kinds of respondents to whom the items would be administered, the class decided that the basic sample should be divided acconding to age, sex, and socio-economic level. So that: the number of variables could be somewhat controlled, the basic sample was limited to married Muslims.

Each of the thirteen students in the class was assigned to administer, in the Indonesian language, the attitude questionnaire to thirty-two respondents whom he would select in Bandung where they fitted the defined sex, age, and social class criteria. Each student's sample was divided into an equal number of males and females, younger (ages 18 through 34) and older (ages 35 through 65) people, and an almost equal number from each of three social class levels.

In addition to the foregoing basic sample, forty-six students preparing for careers in social work and currently enrolled in the writer's mental hygiene class also filled out the questionnaire. This student sample consisted of twenty-five married and twenty-one single students; thirty-seven were Muslim and nine were Christians.

The three social class levels were defined in the following manner:

Class 1 (Upper): physician, lawyer, high level business administrator, high level government official, college professor, military or police officer of captain's rank or higher, architect, contractor, engineer, any other occupations of status equal to the foregoing, and a wife of any of these.

Class 2 (Middle): elementary or high school teacher, operator of a small business, mechanic, office worker such as stenographer, army or police sergeant or lieutenant, barber, carpenter, any other occupations of status equal to the foregoing, and a wife of any of these.

Class 3 (Lower): maid or house servant, laborer, pedicab driver, army private or corporal, peddler, farm laborer, any other occupations of equal status to the foregoing, and a wife of any of these. 
In selecting a sample of equal numbers from each of the three social class levels, the survey team was not assuming that such a sample accurately represented the proportions of each social class found in the general population. Clearly, members of Bandung's lower classes greatly outnumbered those of the middle and upper. But the survey team did not know the true proportions of people in the three social classes, so they chose the route of convenience and selected equal numbers at each level, keeping this bias in mind when the results were later interpreted. The composition of the final sample is shown in Table 1. The usable questionnaires from the basic sample totalled 397 . These, together with the forty-six students, made up the total sample of 443 .

Table 1

Nature of Survey Sample

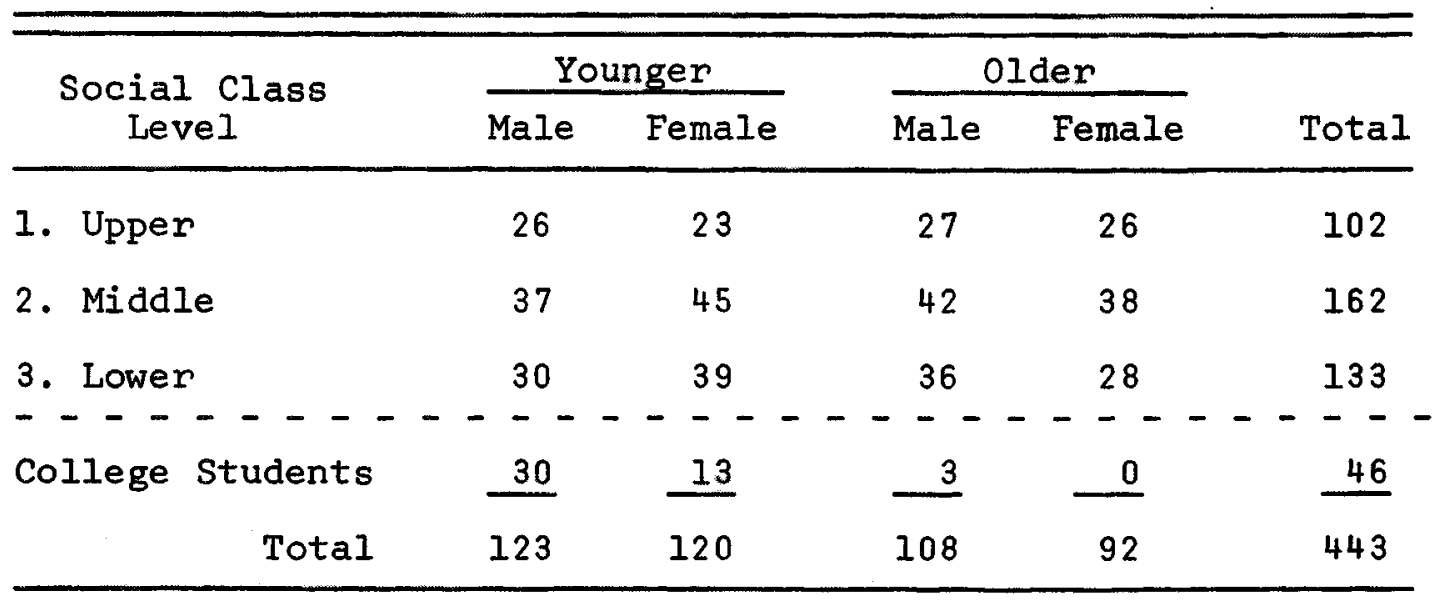

Total males, 231; females, 212; younger, 243; older, 200.

of the twenty-four items on the questionnaire, the fourteen which seemed to elicit the most meaningful answers are reported in this paper. These items, arranged in an approximate order from the most in favor of birth control to the most opposed to it, appear in Table 2. (When the questions were administered to respondents, the items were presented in a random order, not in the ranked order shown in Table 2.) If a respondent's reading ability was in question, the instrument was administered orally. Those people whose ability to read was obviously satisfactory were permitted to complete the scale on their own.

In planning the interview technique, the survey team faced the problem of insuring that all interviewees had defined 
Table 2

Respondents' Agreement with Statements About Birth Control

\begin{tabular}{|c|c|c|c|c|c|}
\hline & Statements & $\begin{array}{l}\text { I } \\
\text { \& of } 443 \\
\text { Respondents } \\
\text { Who Agree }\end{array}$ & $\begin{array}{l}\text { II } \\
\text { t-ratio* } \\
\text { Male vs. } \\
\text { Female }\end{array}$ & $\begin{array}{l}\text { III } \\
\text { t-ratio* } \\
\text { Youth } \\
\text { vs. Aged }\end{array}$ & $\begin{array}{l}\text { IV } \\
\text { t-ratio* } \\
\text { Upper vs: } \\
\text { Lower class }\end{array}$ \\
\hline 1. & $\begin{array}{l}\text { Birth control is a most respected, } \\
\text { honored practice. }\end{array}$ & 19.6 & F 2.0 & Y 2.4 & .8 \\
\hline 2. & $\begin{array}{l}\text { The practice of birth control contributes } \\
\text { to the progress of society and the nation. }\end{array}$ & 58.0 & $\mathrm{~F} \quad .8$ & $Y 2.4$ & U 1.8 \\
\hline 3 . & $\begin{array}{l}\text { Birth control is needed in the sections } \\
\text { of the country which are too crowded. }\end{array}$ & 80.8 & F 1.1 & Y 1.1 & U 2.7 \\
\hline & $\begin{array}{l}\text { Birth control may be practiced by peo- } \\
\text { ple who already have many children. }\end{array}$ & 83.5 & $\mathrm{~F} \quad .3$ & Y 1.6 & U 3.7 \\
\hline & $\begin{array}{l}\text { The decision about whether or not to } \\
\text { practice birth control should be left } \\
\text { up to the wife and husband concerned. }\end{array}$ & 86.1 & $F 3.0$ & Y 1.8 & $\mathrm{U} 4.4$ \\
\hline & $\begin{array}{l}\text { It is not necessary for the government } \\
\text { to become involved with the issue of } \\
\text { birth control. }\end{array}$ & 44.0 & F 1.5 & A 2.3 & L 1.5 \\
\hline & $\begin{array}{l}\text { The people should be informed of the } \\
\text { disadvantages of birth control } \\
\text { practices. }\end{array}$ & 80.1 & M . . & A 1.0 & .4 \\
\hline & $\begin{array}{l}\text { Practicing birth control may damage } \\
\text { a woman's health. }\end{array}$ & 47.9 & F 1.6 & A .4 & L 2.9 \\
\hline
\end{tabular}


Table 2 (Continued).

\begin{tabular}{|c|c|c|c|c|}
\hline Statements & $\begin{array}{c}I \\
\% \text { of } 443 \\
\text { Respondents } \\
\text { Who Agnee }\end{array}$ & $\begin{array}{c}\text { II } \\
\text { t-ratio* } \\
\text { Male vs. } \\
\text { Female }\end{array}$ & $\begin{array}{l}\text { III } \\
\text { t-ratio* } \\
\text { Youth } \\
\text { vs. Aged }\end{array}$ & $\begin{array}{c}\text { IV } \\
\text { t-ratio* } \\
\text { Upper vs. } \\
\text { Lower Class }\end{array}$ \\
\hline
\end{tabular}

9. Practicing birth control may reduce an individual's ability to work hard

28.9

F 1.2

A 1.4

L 2.2

10. Birth control interferes with the harmony of the home.

43.3

F 2.2

$\mathrm{Y} 1.8$

L 3.9

11. Practicing birth control brings suffering to the wife.

39.1

F 2.8

A 2.5

L 4.5

12. Abortion is an act of murder.

77.9

M . .5

A $\quad .6$

U 1.4

13. The practice of birth control stimulates the growth of prostitution.

42.4

F. .4

$\mathrm{Y} \quad .1$

L 2.4

14. Birth control practices conflict with the Islamic and Christian religions.

68.2

F 1.3

A 1.9

L 4.4

* In the case of each t-ratio, the letter preceding the ratio indicates which percentage in the comparison was the higher, and the number indicates the magnitude of the $t-r a t i o$. The t-ratios 2.0 and greater are significant beyond the .05 level of confidence. Those 2.6 and greater are significant beyond the .01 level. 
birth control in the same way. The only way such assurance could have been achieved would have been for the interviewer to explain in detail each variety of birth control techniques known in modern Indonesian society. The survey team felt, however, that such a "lesson" prior to asking the respondent to answer the questionnaire would discourage many interviewees. In addition, the birth control issue was at the time a politically "touchy" topic and members of the team felt they might appear to be advocating practices contrary to President sukarno's views if they prefaced their questionnaire with instruction in birth control techniques. Consequently, the team decided to offer each respondent no more than the following general definition:

At the present time a topic that is rather often discussed in the newspapers is birth control. By birth control (pembatasan kelahiran) we mean any method that is intentionaliy used to limit the number of children born to a family or used to prevent pregnancy.

Because birth control was described in such broad terms, it seems reasonable that different interviewees brought different specific meanings to certain questionnaire items, because their prior experiences with birth control had differed.

\section{The Results}

To answer the initial research question (To what extent does the Bandung sample agree with President Sukarno that birth control measures are not needed to care for overcrowding in Indonesia?), the writer analyzed respondents' answers to Item 3 on the questionnaire to the effect that: Birth control is needed in the sections of the country which are too crowded.

Responses to Item 3 showed that the large majority (between $72 \%$ and $87 \%$ ) of the interviewees did not agree with the President on the issue. Rather, they believed birth control was needed in crowded districts, of which Bandung would be considered one. Responses of men (79.8\%) and women ( $81.9 \%$ ) were substantially the same, as were the opinions of people below age $35(82.7 \%)$ and those age 35 and above $(78.5 \%)$.

When the data were analyzed by social class levels, it became clear that the higher a person's position in the class structure was, the more likely he would support birth control to alleviate crowding. Within the upper class $87.2 \%$ agreed with Item 3 , within the middle $82.7 \%$, and within the lower $72.2 \%$. (Though the difference between upper and middle was not statistically significant at the .05 level, the difference between middle and lower was significant at the .03 level and that be.tween upper and lower significant beyond the .005 level.) The 
student group ( $84.7 \%$ ) scored between the upper and middle classes--a result consistent with the fact that college students are mostly drawn from the upper and middle strata of the society.

Table 2, in addition to verifying a disagreement between President and populace, suggests the Bandung sample's beliefs about other birth control issues. As Column I indicates, approximately four-fifths of the 443 respondents believed that the decision about practicing birth control should be in the hands of the husband and wife concerned rather than in the hands of some other agency, presumably governmental or religious. About the same proportion thought that birth control might suitably be practiced by people who already had children and that people should be informed about the disadvantages of birth control practices. Slightly more than half of the interviewees believed birth control contributed to national progress. Less than half thought the government should adopt a hands-off policy on the birth control issue. However, seventy-eight percent equated abortion with murder, more upper class respondents than lower class ones holding this opinion. Slightly less than half believed birth control practices brought such deleterious results as increased prostitution, suffering to the wife or damage to her health, and a disruption in the harmony of the home. Nearly one-quarter thought practicing birth control reduced a person's ability to work hard. Only one-fifth of the respondents elevated birth control practices to the position of "highly respected practice."

Columns II, III, and IV of Table 2 report the way subgroups of the total sample answered the fourteen questions. To economize space, the percentages of people within subgroups who agreed with the questionnaire statements are not reported. Instead, only the $t$-ratios are shown. The letter preceding each t-ratio indicates which percentage was larger in each comparison.

The most obvious fact shown in column II is that women expressed a greater agreement with questionnaire statements at all levels of the scale than did men. The preponderance of $F$ symbols preceding t-ratios indicates that on twelve of the fourteen statements the percentage of females exceeded that of males. How this phenomenon is best interpreted is not at all clear to the writer. Perhaps it means simply that more women feel strongly about birth control issues than do men, whether the feeling be pro or con, but a variety of other speculations as to the motives for their positive replies might easily be made. In any event, most of the male-female differences were so slight as to be of little on no significance. Only four of the t-ratios were sufficiently large ( 2.0 or more) to pass the .05 level of statistical significance. These four show that women more often considered birth control a respected practice, believed 
husband and wife should make the decision about whether to adopt birth control measures, and thought birth control might disrupt the home and bring suffering to the wife.

Column III, which pits youth (ages 18-34) against age (ages 35-65) suggests that to some degree younger respondents were more favorable toward birth control measures than were older ones. When we recall that the fourteen items are listed in a general order from those statements most favorable to birth control to those most opposint it, we see that tye $Y$ symbols (youth) dominate among the initial statements and A symbols (aged) among the later ones. As with the male-female comparisons, the differences between young and old were so small on many of the items that it would appear unwise to regard them as highly significant; however, the trend seems sufficiently apparent to be considered not simply a chance occurrence.

Though attitude differences of males versus females and youth versus age were generally small, the differences found between upper and lower socio-economic classes were generally large. The meaning of the pattern of differences among the fourteen items seems unequivocal: upper class respondents were much more favorable toward birth control measures and more enlightened about the effects of birth control than were lower-class respondents. In Column IV the U symbols (upper class) not only dominate among pro-birth control statements and the $L$ symbols (lower class) among anti-birth control items, but nine of the fourteen differences are significant beyond the .05 level. Several of these t-ratios are of such magnitude $(3.9,4.4,4.5)$ as to warrant great confidence in the trend they illustrate.

\section{Discussion}

Before inspecting possible implications of this survey, we may recall the Indonesian political scene at the time the birthcontrol survey was conducted so as to compare it with political conditions that obtain today and may obtain in the future. When the survey was made in early 1965, President Sukarno was still functioning securely as the nation's charismatic leader and chief policy spokesman. Coincidental with the three-week period of the survey, the Indonesian press and radio were giving prominent attention to a national transmigration conference at which public officials expressed opinions about what transmigration measures needed to be taken to relieve the overcrowding of Java. President Sukarno, speaking before the conference delegates, reaffirmed his disapproval of birth control and his endorsement of transmigration. Other conference speakers and writers of editorials supported his position. Thus, at the time of the attitude survey, official opposition to birth control as a means for attacking the problem of overcrowding was particularly visible to the reading public. Yet even in such a political atmosphere, between $72 \%$ and $87 \%$ of the interviewees favored birth control for limiting population growth. 
Let us now turn to some future actions that might be suggested by the results of this survey.

First, it would appear unwise to assume that the attitudes reflected in this sample from Bandung would necessarily represent attitudes in other sectors of the nation. Observers of Indonesian social structure have noted urban-rural splits on various social issues, and such might be true also of birth control attitudes. Villagers who are relatively untouched by Western influence might well respond differently to questions on birth control than did the residents of Bandung, which is a major educational center strongly influenced by the West. The effect of Sukarno's birth control viewpoints on respondents is another factor that might differ with various sections of the country. As events following the October 1965 coup attested, Bandung was not a stronghold of sukarno disciples, so the President's birth control views--if indeed they were known by the nonreaders of newspapers--might be expected to have little effect upon many of the Bandung respondents. On the other hand, in the strong pro-Sukarno areas of East and Central Java, his views might have carried more weight. In any case, it would appear desirable to survey attitudes about birth control in other sectors of the nation before conclusions are drawn about the viewpoints of the population as a whole. Second, it would be useful in future surveys to pose questions that reveal interviewees' attitudes toward each specific birth control technique. The recent government tolerance for, or encouragement of, open discussion of birth control has likely produced a social-psychological climate better suited to such a detailed, forthright investigation than the climate that existed in early 1965 .

But now, for sake of discussion, if we might assume that the survey reported above rather accurately represents the views of the population of Bandung and of similar districts, what implications for action would appear reasonable? Initially, the results suggest that in general the people would favor a policy of birth control to relieve population overcrowding. But we do not know whether they would willingly practice birth control themselves or whether they only want the policy applied to other Indonesians--perhaps only to ethnic groups other than their own. This obviously is an important matter for more detailed investigation.

Next, the results suggest that if the government wishes to mount a campaign to enlist support for family planning, it should focus its campaign primarily on lower class families, for lower class respondents were the ones who indicated less enthusiasm for, and less understanding about, birth control measures. Advocates of family planning might, however, take heart in the fact that the age grouping most capable of producing babies (ages 18 through 34 ) looked with greater favor-- 
at least to a slight degree--on birth control than did older, less fertile respondents. Finally, the results indicate that if the government wishes to include abortion as an accepted birth control technique, considerable opposition to the plan could be expected from the populace, given the very high percentage of the respondents who equated abortion with murder. 